\title{
Effects of Entrepreneurial Orientation on Performance and Growth: Are Microenterprises and Small Firms Equal?
}

\author{
Elena Patricia Mojica-Carrillo', Gonzalo Maldonado-Guzmán², Sandra \\ Yesenia Pinzón-Castro ${ }^{3}$ and Angie Lorena Riaño-Castillo ${ }^{4}$
}

\begin{abstract}
Entrepreneurial orientation is one of the constructs that is increasingly gaining the attention of researchers, academics and industry professionals, and is considered in the current literature as one of the business strategies that generates, both a higher level of financial performance and growth in companies. However, there are relatively few studies published in the entrepreneurship literature that analyze the relationship between entrepreneurial orientation, financial performance and the level of growth of small companies, especially in emerging economy countries, as is the case from Mexico. For this reason, through a sample of 300 micro and small companies, the essential objective of this study is the analysis of the effects of company size on the relationship between entrepreneurial orientation, financial performance and growth of companies.

The results obtained show that the entrepreneurial orientation has significant positive effects both on financial performance and on the level of growth of micro and small companies.
\end{abstract}

\section{JEL classification numbers: M21}

Keywords: Open innovation practices, Product development, Firm performance, Manufacturing firms.

${ }^{1}$ Universidad Autónoma de Aguascalientes, Centro de Ciencias Económicas y Administrativas, Departamento de Mercadotecnia.

${ }^{2}$ Universidad Autónoma de Aguascalientes, Centro de Ciencias Económicas y Administrativas, Departamento de Mercadotecnia.

${ }^{3}$ Universidad Autónoma de Aguascalientes, Centro de Ciencias Económicas y Administrativas, Departamento de Mercadotecnia.

${ }^{4}$ Universidad Autónoma de Aguascalientes, Centro de Ciencias Económicas y Administrativas, Estudiante del Doctorado en Ciencias Administrativas. 


\section{Introduction}

Micro and small enterprises play an essential in job creation and the socioeconomic development of most countries in the world (Wolcott et al., 2008; Bowen et al., 2009), especially in developing countries with an emerging economy (Al-Mamun et al., 2016), since a high level of micro and small firms can adjust the processes to the requirements and needs of the market (Wolcott et al., 2008). Similarly, in most countries in the world, particularly developing countries, as it is the case of Mexico, micro and small enterprises are basically classified by their annual sales and the number of employees they have (Al-Mamun \& Ali-Fazal, 2018), and most of this type of organizations carry out retail activities in the region and country where they are established (Ahman \& Zabri, 2018).

Accordingly, most micro and small firms are labeled as entrepreneurial in the literature and they tend to be more innovative, take bigger risks and be proactive (Miller, 1983; Covin \& Slevin, 1989). For this reason, entrepreneurial orientation has attracted a lot of attention from researchers, scholars and professionals of entrepreneurism by publishing several investigations that have analyzed the close relationship, between the different dimensions of entrepreneurial orientation and financial performance in micro and small enterprises (Andersén \& Samuelsson, 2016). Moreover, some researches that have used the meta-analysis in the relation between entrepreneurial orientation and financial performance have found a positive and significant relation between both constructs (Rauch et al., 2009; Saeed et al., 2014).

Nonetheless, the relation between entrepreneurial orientation and financial performance tends to be too complex and different researchers and scholars have discovered other factors that affect this relation (Lumpkin \& Dess, 1996; Lyon et al., 2000; Wiklund \& Shepherd, 2005). That is why further theoretical and empirical investigations have to focus in the analysis of other resources or factors that, combined with entrepreneurial orientation, have more impact in the financial performance and one of them could be firm growth (Wiklund \& Shepherd, 2003; Zahra et al., 2004; O'Shea et al., 2005; Wales et al., 2013). Thus, entrepreneurial orientation will allow micro and small enterprises to identify the current market opportunities in a way that they can benefit from them and get better business results (Álvarez \& Busenitz, 2001).

Furthermore, different published investigations in the literature of entrepreneurism have analyzed intensively several external factors with the entrepreneurial orientation like environmental dynamism (e.g., Lumpkin \& Dess, 2001; Wiklund \& Shepherd, 2005). However, the effects of entrepreneurial orientation in financial performance has not been analyzed or discussed in depth (Andersén \& Samuelsson, 2016). Therefore, the publications of papers that link entrepreneurial orientation with financial performance have considered different measurements of performance, including growth and profit (Wiklund \& Shepherd, 2005; De Clercq et al., 2010). Nonetheless, the effects of entrepreneurial orientation in financial performance and firm growth in micro and small firms have usually been carried out and discussed 
in a separate way instead of together (Andersén \& Samuelsson, 2016).

Within this set of ideas, this empirical research can contribute significantly in the current literature of entrepreneurism through the analysis and discussion of the effects of entrepreneurial orientation in financial performance and firm growth of the manufacturing industry in both micro and small enterprises, as suggested by Lumpkin and Dess (1996), Wiklund and Shepherd (2005), Saeed et al. (2014), Andersén and Samuelsson (2016) as well as Al-Mamun and Ali-Fazal (2018) since the relationship between these three constructs represents an important area of interest of investigation for researchers and scholars (Saeed et al., 2014).

\section{Preliminary Notes}

There is in the literature of entrepreneurism an agreement among researchers and scholars that the activities of entrepreneurial orientation can benefit enterprises that do not have enough financial resources and low technological support, as it is the case of micro and small enterprises (Peric et al., 2017; Al-Mamun et al., 2018), since entrepreneurial orientation is generally regarded as the skills that enterprises have to use adequately the resources they have to improve significantly their levels of financial performance and firm growth (Al-Mamun et al., 2016). In this trend of ideas, Mitchelmore and Rowley (2010) concluded in their investigation that entrepreneurial orientation activities can be considered as an essential requirement, for the success in the creation of new enterprises as well as the current micro and small firms.

Likewise, Man et al. (2002) had already considered that entrepreneurial managers have higher probabilities of making changes in their management activities more efficiently, when compared with those who are not entrepreneurial. Moreover, Gerli et al. (2011) also recognized that entrepreneurial managers tend to develop more their skills and attain better levels of financial performance; that is why it is possible to establish that skills and abilities create a higher level of financial performance as well as a higher firm growth (Mitchelmore \& Rowley, 2013). Thus, entrepreneurial orientation is considered in the current literature as one of the fundamental factors, that can increase significantly the external and internal abilities and skills of micro and small enterprises which allows them to obtain more and better business results (Darwis, 2017).

Thus, entrepreneurial orientation normally produces positive and significant effects in financial performance (Caseiro \& Coelho, 2018). When it is linked to relational and human capital it also creates positive and significant effects in the performance of micro and small enterprises (Radulovich et al., 2018). Similarly, entrepreneurial orientation is also considered as a key construct of firm growth (Hakala, 2013), in addition to the fact that it can generate different competitive advantages (Rauch et al., 2009). Additionally, entrepreneurial orientation can create and/or increase the innovation skills of enterprises substantially (Levinthal \& March, 1993), and moderate the current relation between the resources based on knowledge and financial performance (Dess \& Lumpkin, 2005). 
In this regard, several investigations published in the current literature of entrepreneurism usually include innovativeness, risk taking and proactivity as basic requirements of entrepreneurial orientation (Al-Mamun \& Ali-Fazal, 2018), as it potentially determines to a high degree the success of enterprises as well as the economic development of countries (Al-Mamun \& Ali-Fazal, 2018). However, it is important that researchers, scholars and professionals in the field of entrepreneurism focus their empirical investigations on each one of the three key elements or dimensions of entrepreneurial orientation (innovativeness, risk taking and proactivity), in order to analyze in a more detailed way their effects on financial performance and firm growth (Mitchelmore \& Rowley, 2010; Andrews et al., 2011; Gerli et al., 2011).

From a perspective of micro and small enterprises, the literature points out that three out of five enterprises of these categories disappear within the first five months of their business activities (Bowen et al., 2009). In order to show this more clearly, observed the lack of an adequate competence of human resources of micro and small firms which is one of the essential changes that this type of organizations have to carry out to survive in the market there they participate (Al-Mamun \& Ali-Fazal, 2018). Clearly, there is a vacuum in the current literature about the main factors that cause this issue that affect the financial performance and growth of micro and small enterprises (Al-Mamun \& Ali-Fazal, 2018). That is why it is important to identify the effects that entrepreneurial orientation has on financial performance and firm growth, especially those located in developing countries (Al-Mamun et al., 2016). Accordingly, it is common to find in the literature that an entrepreneurial person is the one that usually takes risks in their business activities and is prone to carry out substantial changes in the organization, in order to obtain more and better results (Coda et al., 2018). Therefore, the aim of entrepreneurs is to make their business more competitive so that is why several published papers in the literature have focused in the analysis and discussion of this close relation, including other variables of essential results just like financial performance (Cho \& Moon, 2013). Furthermore, when the investigations are matched with entrepreneurial orientation and the performance of micro and small enterprises, they become more relevant for the high percentage of early closure of this type of enterprises (Coda et al., 2018), and due to the low level of risk taking (Hisrich et al., 2014).

Moreover, the results obtained recently in the literature of entrepreneurism (e.g., Bula, 2012; Blackburn et al., 2013; Mas-Tur et al., 2015; Andersén \& Samuelsson, 2016; Al-Mamun \& Ali-Fazal, 2018; Coda et al., 2018), have verified the tendency that organizations have towards innovation, capitalization of opportunities provided by the market (proactivity), and the planning capacity of activities that imply risk taking, essential characteristics of entrepreneurial orientation. More specifically, the research of Blackburn et al. (2013) has focused in explaining the entrepreneurial orientation of small firms and the investigation of discussed the characteristics of small entrepreneurial enterprises from Latin America, especially their tendency to carry out innovation activities. 
Additionally, some researchers and scholars have suggested that entrepreneurial orientation should be examined by deconstructing each one of the concepts that form it and analyze each one of their dimensions in a separate way (e.g., Lumpkin \& Dess, 1996, 2001; Wiklund \& Shepherd, 2003, 2005). However, other researchers and scholars considered that entrepreneurial orientation should be investigated as another additional construct, mostly because in the entrepreneurial literature it is establish that in order for an enterprise to be regarded as entrepreneurial it has to carry out innovation activities, take risks and be proactive (Miller, 1983; Covin \& Slevin, 1986, 1989, 1991), since the three dimensions of entrepreneurial orientation are closely related to each other (Covin et al., 2006; Keh et al., 2007).

Similarly, for the entrepreneurial orientation to have positive and significant effects in the financial performance, the organizations will have to keep looking for new opportunities to identify new flows of revenues that allow them to get a higher level of grow (Lumpkin \& Dess, 1996). Therefore, enterprises have to carry out innovation activities constantly by taking the necessary risks, with the design of their market strategies as well as making efforts to anticipate the demand of their products (e.g., proactive), which will lead to a higher level of financial performance (Rauch et al., 2009). Furthermore, Rauch et al. (2009) and Saeed et al. (2014), carried out investigations by using a meta-analysis in order to prove the relation between entrepreneurial orientation and financial performance, and they found positive and significant effects between both constructs.

Thus, some researchers and scholars have pointed out that the relationship between entrepreneurial orientation and financial performance is a lot more complex than it seems as entrepreneurial orientation has practically more positive and significant influence in financial performance under certain circumstances (George et al., 2001; Dimitratos et al., 2004; Messersmith \& Wales, 2011). Therefore, it is possible to establish that the relation between entrepreneurial orientation and financial performance is a lot stronger, and more significant when firm growth is included in decision making (Andersén \& Samuelsson, 2016). Hence, considering the information presented above, it is possible to establish the first research hypothesis.

H1: There are significant differences about the size of firms between entrepreneurial orientation and financial performance.

Some published papers in the literature state that the relation between entrepreneurial orientation and financial performance is moderate, and it increases depending on the level of uncertainty on terms of the environmental dynamism (Lumpkin \& Dess, 1996; Wiklund \& Shepherd, 2005). Nonetheless, the source of internal uncertainty of business has not been analyzed in depth, especially about the uncertainty of firm growth (Andersén \& Samuelsson, 2016), which is why there are strong arguments in the literature of some researchers, scholars and professionals in the field of entrepreneurism that entrepreneurial orientation can affect financial performance, in a different whether the company has achieved or not a significant growth (Andersén \& Samuelsson, 2016). 
Within this context, micro and small enterprises can achieve a higher level of growth if it increases the current demand in the market or if the organization enters in new markets, with new or existing products even when the growth, in terms of sales increase, normally demands changes and take risks (Davidsson, 1991; Moreno $\&$ Casillas, 2008). For these reasons, the uncertainty creates in the organizations, mostly micro and small enterprises, a series of modifications such as the employment of new staff or more training of the current personnel (Wiklund et al., 2003), or possibly pressure enterprises to develop more entrepreneurial activities in new markets in order to achieve a higher level of growth (McKelvie et al., 2011). In this regard, there is an increasing number of papers that analyze entrepreneurial orientation that have considered firm growth as a dependent variable (e.g. Cassia \& Minola, 2012; Wolff et al., 2015), as there are different published investigations in the literature that have established the importance of adapting the management practices at the level of growth that enterprises achieve (Andersén \& Samuelsson, 2016). A clear example of this are some of the recent papers that have showed that the growth of enterprises demands, a higher level of entrepreneurism when compared with companies that achieved a lower level of growth (Davila, 2005; Davila \& Foster, 2005), and some other investigations have obtained evidence that organizations that have a higher level of growth manage their human resources better (Heneman et al., 2000; Hughes \& Morgan 2007).

Likewise, there are only a few published papers in the literature of entrepreneurism have analyzed and discussed the effects of entrepreneurial orientation at the level of firm growth, mostly in small enterprises (Andersén \& Samuelsson, 2016), since normally this type of organizations, just like micro enterprises, have low levels of growth. What some researchers and scholars try to identify is a universal relation between entrepreneurial orientation and the different indicators of financial performance, including the level of growth of micro and small enterprises (Hughes \& Morgan, 2007; Messersmith \& Wales, 2011).

Moreover, the combination of entrepreneurial orientation with financial performance can affect more the level of firm growth (Messersmith \& Wales, 2011), which is why organizations, especially micro and small enterprises, have to redirect their entrepreneurial strategy to obtain both a higher level of financial performance and a higher growth (Andersén \& Samuelsson, 2016). However, the literature considers that it is not enough that enterprises are entrepreneurial; they also have to carry out an efficient use of their resources (Cassia \& Minola, 2012), which will allow them to get a higher level of growth (Andersén \& Samuelsson, 2016). Therefore, considering the information presented above, it is possible to establish the second research hypothesis.

H2: There are significant differences about the size of firms between entrepreneurial orientation and firm growth. 
An empirical research of micro and small enterprises of the manufacturing in Aguascalientes (Mexico) was carried out in order to answer the hypotheses established by using as reference framework the business directory of the Sistema de Información Empresarial Mexicano (System of Mexican Business Information) for Aguascalientes State in 2018 which had 1,527 registered enterprises, each one containing from 5 to 250 workers at the end of November. Moreover, an instrument of data collection was designed to be answered by managers and/or owners of micro and small enterprises, which were selected through a random sampling with a maximum error of $\pm 5 \%$ and a level of reliability of $95 \%$ which took place between January and March of 2019.

Accordingly, a scale proposed by Miller (1983) was used for the measurement of entrepreneurial orientation. The author considered that entrepreneurial orientation can be measured through three dimensions: Innovativeness (measured trough six items); Risk Taking (measured trough six items), and Proactivity (measured trough six items). Moreover, the financial performance was measured through the scale proposed by Leonidou et al. (2013), who considered that the financial performance can measured through seven items. All the items considered of the scales of entrepreneurial orientation and financial performance were measured through a Likert-type scale of five positions from " $1=$ completely disagree" to " $5=$ completely agree" as limits.

Regarding the aspect of growth, it was measured through the sales made by micro and small enterprises in 2018 (Autio \& Lumme, 1998; Ballow et al., 2004; Salojärvi et al., 2005; Linder, 2006; Carneiro, 2007; Kruger \& Johnson, 2009), because in order to estimate the potential of growth a qualitative evaluation of managers is usually considered as sales are the main indicator (Autio \& Lumme, 1998). Furthermore, a Second-Order Multi-Group Confirmatory Factor Analysis (SEMGCFA) was carried out to evaluate the reliability and validity of the scales of entrepreneurial orientation and financial performance, by using the method of maximum likelihood with the software EQS 6.2 (Bentler, 2005; Brown, 2006; Byrne, 2006). Thus, the reliability was measured with Cronbach's alpha as well as the Composite Reliability Index (CRI) (Bagozzi \& Yi, 1988).

The results obtained from SEMGCFA are shown in Table 1 and show that the theoretical model analyzed has a good adjustment of data $\left(S-B X^{2}=1,256.023 ; d f=\right.$ 534; $p=0.000 ; N F I=0.824 ; N N F I=0.895 ; C F I=0.917 ; R M S E A=0.079$ ). Likewise, the values of Cronbach's alpha and the CRI are higher than 0.7, which indicates the reliability on the scale of entrepreneurial orientation (Nunally \& Bernstein, 1994; Hair et al., 2010). All the items of the factors related are significant ( $\mathrm{p}<0.001)$. The value of all the standardized factorial loads is higher than 0.6 (Bagozzi \& Yi, 1988), and the Extracted Variance Index (EVI) of each pair of constructs of the theoretical model has a value over 0.5 (Fornell \& Larcker, 1981). These values indicate that the theoretical model has a good adjustment of data and provide evidence of the presence of convergent validity. 
Table 1: Internal consistency and convergent validity of the theoretical model

\begin{tabular}{|c|c|c|c|c|c|c|}
\hline Variable & Indicator & $\begin{array}{c}\text { Factorial } \\
\text { Loading }\end{array}$ & $\begin{array}{l}\text { Robust } \\
\text { t-Value }\end{array}$ & $\begin{array}{c}\text { Cronbach's } \\
\text { Alpha }\end{array}$ & CRI & EVI \\
\hline \multicolumn{7}{|c|}{ Microenterprises } \\
\hline \multirow{6}{*}{$\begin{array}{l}\text { Innovativeness } \\
\text { (F1) }\end{array}$} & IN1 & $0.760 * * *$ & $1.000^{\mathrm{a}}$ & \multirow{6}{*}{0.938} & \multirow{6}{*}{0.939} & \multirow{6}{*}{0.722} \\
\hline & IN2 & $0.785 * * *$ & 9.208 & & & \\
\hline & IN3 & $0.790 * * *$ & 6.926 & & & \\
\hline & IN4 & $0.904 * * *$ & 10.170 & & & \\
\hline & IN5 & $0.954 * * *$ & 10.855 & & & \\
\hline & IN6 & $0.888 * * *$ & 9.945 & & & \\
\hline \multirow{6}{*}{$\begin{array}{l}\text { Risk-Taking } \\
\text { (F2) }\end{array}$} & TR1 & $0.724 * * *$ & $1.000^{\mathrm{a}}$ & \multirow{6}{*}{0.921} & \multirow{6}{*}{0.922} & \multirow{6}{*}{0.667} \\
\hline & TR2 & $0.674 * * *$ & 13.266 & & & \\
\hline & TR3 & $0.857 * * *$ & 9.000 & & & \\
\hline & TR4 & $0.922 * * *$ & 7.238 & & & \\
\hline & TR5 & $0.853 * * *$ & 8.677 & & & \\
\hline & TR6 & $0.842 * * *$ & 5.727 & & & \\
\hline \multirow{6}{*}{$\begin{array}{l}\text { Proactivity } \\
\text { (F3) }\end{array}$} & PR1 & $0.707 * * *$ & $1.000^{\mathrm{a}}$ & \multirow{6}{*}{0.943} & \multirow{6}{*}{0.944} & \multirow{6}{*}{0.739} \\
\hline & PR2 & $0.860 * * *$ & 8.373 & & & \\
\hline & PR3 & $0.852 * * *$ & 7.445 & & & \\
\hline & PR4 & $0.934 * * *$ & 9.245 & & & \\
\hline & PR5 & $0.892 * * *$ & 5.720 & & & \\
\hline & PR6 & $0.893 * * *$ & 5.269 & & & \\
\hline \multirow{3}{*}{$\begin{array}{c}\text { Entrepreneurial } \\
\text { Orientation }\end{array}$} & F1 & $0.661 * * *$ & 4.089 & \multirow{3}{*}{0.904} & \multirow{3}{*}{0.905} & \multirow{3}{*}{0.765} \\
\hline & F2 & $0.983 * * *$ & 5.116 & & & \\
\hline & F3 & $0.965 * * *$ & 5.071 & & & \\
\hline \multirow{7}{*}{$\begin{array}{c}\text { Financial } \\
\text { Performance }\end{array}$} & FP1 & $0.632 * * *$ & $1.000^{\mathrm{a}}$ & \multirow{7}{*}{0.932} & \multirow{7}{*}{0.933} & \multirow{7}{*}{0.673} \\
\hline & FP2 & $0.654 * * *$ & 10.937 & & & \\
\hline & FP3 & $0.741 * * *$ & 8.579 & & & \\
\hline & FP4 & $0.752 * * *$ & 6.454 & & & \\
\hline & FP5 & $0.906^{* * *}$ & 7.739 & & & \\
\hline & FP6 & $0.981 * * *$ & 8.177 & & & \\
\hline & FP7 & $0.992 * * *$ & 8.231 & & & \\
\hline \multicolumn{7}{|c|}{ Small Firms } \\
\hline & IN1 & $0.815 * * *$ & $1.000^{\mathrm{a}}$ & & & \\
\hline & IN2 & $0.807 * * *$ & 15.715 & & & \\
\hline Innovativeness & IN3 & $0.821 * * *$ & 11.800 & & & \\
\hline (F1) & IN4 & $0.854 * * *$ & 10.827 & 0.934 & 0.936 & 0.708 \\
\hline & IN5 & $0.893 * * *$ & 11.964 & & & \\
\hline & IN6 & $0.855 * * *$ & 11.987 & & & \\
\hline & TR1 & $0.755 * * *$ & $1.000^{\mathrm{a}}$ & & & \\
\hline & TR2 & $0.678 * * *$ & 14.716 & & & \\
\hline Risk-Taking & TR3 & $0.767 * * *$ & 10.556 & & & \\
\hline (F2) & TR4 & $0.880 * * *$ & 11.535 & 0.891 & 0.893 & 0.585 \\
\hline & TR5 & $0.814 * * *$ & 9.718 & & & \\
\hline & TR6 & $0.673 * * *$ & 6.601 & & & \\
\hline & PR1 & $0.699 * * *$ & $1.000^{\mathrm{a}}$ & & & \\
\hline Proactivity & PR2 & $0.827 * * *$ & 11.943 & & & \\
\hline (F3) & PR3 & $0.833 * * *$ & 10.016 & 0.910 & 0.912 & 0.635 \\
\hline & PR4 & $0.826 * * *$ & 8.733 & & & \\
\hline
\end{tabular}




\begin{tabular}{|c|c|c|c|c|c|c|}
\hline & PR5 & $0.806 * * *$ & 7.891 & & & \\
\hline & PR6 & $0.783 * * *$ & 7.247 & & & \\
\hline \multirow{3}{*}{$\begin{array}{c}\text { Entrepreneurial } \\
\text { Orientation }\end{array}$} & F1 & $0.671 * * *$ & 4.475 & \multirow{3}{*}{0.744} & \multirow{3}{*}{0.746} & \multirow{3}{*}{0.502} \\
\hline & F2 & $0.800 * * *$ & 9.568 & & & \\
\hline & F3 & $0.634 * * *$ & 3.061 & & & \\
\hline \multirow{7}{*}{$\begin{array}{c}\text { Financial } \\
\text { Performance }\end{array}$} & FP1 & $0.694 * * *$ & $1.000^{\mathrm{a}}$ & \multirow{7}{*}{0.917} & \multirow{7}{*}{0.919} & \multirow{7}{*}{0.621} \\
\hline & FP2 & $0.750 * * *$ & 17.971 & & & \\
\hline & FP3 & $0.771 * * *$ & 8.871 & & & \\
\hline & FP4 & $0.798 * * *$ & 11.247 & & & \\
\hline & FP5 & $0.857 * * *$ & 10.569 & & & \\
\hline & FP6 & $0.853 * * *$ & 10.391 & & & \\
\hline & FP7 & $0.775 * * *$ & 7.230 & & & \\
\hline
\end{tabular}

The discriminant validity of the theoretical model of entrepreneurial orientation and financial performance was measured through the reliability interval test (Anderson \& Gerbing, 1988), which establishes that with an interval of $95 \%$ of reliability none of the individual latent elements of the matrix of correlation must have a value of 1 . Therefore, based on the results obtained from the test, it can be concluded that there is enough evidence of the presence of discriminant validity. Table 2 shows the results obtained in a more detailed way.

Table 2: Discriminant validity of the theoretical model

\begin{tabular}{|c|c|c|}
\hline Variables & $\begin{array}{c}\text { Entrepreneurial } \\
\text { Orientation }\end{array}$ & $\begin{array}{c}\text { Financial } \\
\text { Performance }\end{array}$ \\
\hline Entrepreneurial Orientation & & $0.155-0.407$ \\
\hline Financial Performance & $0.283-0.459$ & \\
\hline
\end{tabular}

Above the diagonal the estimated correlation of factors of microenterprises is presented with $95 \%$ confidence interval. Below diagonal, the estimate correlation of factors of small firms is presented with $95 \%$ confidence interval.

\section{Main Results}

In order to answer the research hypotheses established in this empirical research, a second-order structural equations modeling (SOSEM) was applied with software EQS 6.2 (Bentler, 2005; Byrne, 2006; Brown, 2006). Additionally, the nomological validity of the theoretical model of entrepreneurial orientation, financial performance and firm growth was examined through the Chi-square test, which compared the results obtained between the theoretical model and the measurement model. Such results indicate that the differences between both models are not 
significant which can offer an explanation of the relationships observed among the latent constructs (Anderson \& Gerbing, 1988; Hatcher, 1994). Table 3 shows the results the implementation of the model of structural equations in a more detailed way.

Table 3: SEM Results

\begin{tabular}{|l|c|c|c|}
\hline \multicolumn{1}{|c|}{ Hypothesis } & Structural Relationship & $\begin{array}{c}\text { Standardized } \\
\text { Coefficient }\end{array}$ & $\begin{array}{c}\text { Robust } \\
\text { t-Value }\end{array}$ \\
\hline \multicolumn{3}{|c|}{ Microenterprises } \\
\hline $\begin{array}{l}\text { H1A: Higher level } \\
\text { of entrepreneurial } \\
\text { orientation, higher } \\
\text { level firm } \\
\text { performance. }\end{array}$ & E. Orientation $\rightarrow$ Performance & $0.925^{* * *}$ & 10.417 \\
\hline $\begin{array}{l}\text { H2A: Higher level } \\
\text { of entrepreneurial } \\
\text { orientation, higher } \\
\text { level of fir growth. }\end{array}$ & E. Orientation $\rightarrow$ Growth & $0.381^{* * *}$ & 3.267 \\
\hline \multicolumn{3}{|c|}{ Small Firms } & 14.663 \\
\hline $\begin{array}{l}\text { H1B: Higher level } \\
\text { of entrepreneurial } \\
\text { orientation, higher } \\
\text { level firm } \\
\text { performance. }\end{array}$ & E. Orientation $\rightarrow$ Performance & $0.457^{* * *}$ & \\
\hline $\begin{array}{l}\text { H2B: Higher level } \\
\text { of entrepreneurial } \\
\text { orientation, higher } \\
\text { level of fir growth. }\end{array}$ & E. Orientation $\rightarrow$ Growth & 0.171 & 5.519 \\
\hline $\begin{array}{l}\left.S-B X^{2} \text { (df }=524\right)=1,059.579 ; p<0.000 ; N F I=0.867 ; \text { NNFI }=0.945 ; \text { CFI }=0.964 ; \text { RMSEA }=0.073 \\
* * *=P<0.01\end{array}$ & & \\
\hline
\end{tabular}

Table 3 shows the results obtained from the SOSEM. It can be observed that, regarding the research hypotheses $\mathrm{H}_{1 \mathrm{~A}}$ and $\mathrm{H}_{2 \mathrm{~A}}(\beta=0.925 \mathrm{p}<0.001 ; \beta=0.381 \mathrm{p}<$ 0.001 ), the results indicate that entrepreneurial orientation has positive and significant effects in both the financial performance and firm growth of manufacturing micro enterprises. Likewise, the results obtained regarding the research hypotheses $\mathrm{H}_{1 \mathrm{~B}}$ and $\mathrm{H}_{2 \mathrm{~B}}(\beta=0.457 \mathrm{p}<0.001 ; \beta=0.171 \mathrm{p}<0.001)$, also have positive and significant effects in financial performance and firm growth of manufacturing micro enterprises. Therefore, it is possible to establish that the implementation of entrepreneurial orientation will affect financial performance and firm growth, in a positive and significant way on both micro and small enterprises of the manufacturing sector. However, the small organizations showed a lower effect when compared with micro enterprises. 
Similarly, the results obtained in this empirical research have several implications that are important to mention. The first one is that entrepreneurial orientation demands the implementation of a series of innovation activities. In most micro and small enterprises in Mexico, just like the ones from other countries of Latin America, the innovation activities are commonly focused on the implementation of modifications or improvements to current products (incremental innovation), while there are relatively few development activities of new products (radical innovation). These results are consistent with the ones obtained by Berne (2016), who analyzed the degree of innovation in both micro and small enterprises who stated that innovation is not a common activity in this type of companies. That is why managers have to create the necessary conditions for the development of innovation activities. A second implication obtained from these results is that entrepreneurial orientation also implies that managers micro and small enterprises take some risks in their implementation and development because, according to the results of Sadler-Smith et al. (2003), the profile of entrepreneurial managers is closely linked with the management vision that managers of the organizations have, which is why the risks they take will have positive and significant effects in the financial performance of enterprises. Furthermore, Blackburn et al. (2013) concluded that managers of micro and small enterprises have to take some risks in order to take advantage of any opportunities, which can provide them with a higher level of growth and financial performance. That is why managers of micro and small enterprises have to take risks in the development of entrepreneurial orientation activities.

A third implication obtained from these results is that entrepreneurial orientation also demands from managers of micro and small enterprises to be more proactive than reactive. According to the results obtained by Andersson and Tell (2009) in their investigations published in the last 25 years, they concentrated in identifying the characteristics of managers of micro and small enterprises that achieved a higher level of growth. They found that the motivation, behavior and, especially, proactivity of managers are key factors to get more and better results. As a consequence, managers of micro and small enterprises have to be more proactive in the adoption and implementation of entrepreneurial orientation activities, because this will determine in a high percentage the improvement of the levels of financial performance and firm growth.

A fourth implication obtained from these results is that managers of micro and small enterprises must not consider entrepreneurial orientation just as another business strategy of the organization, but rather as another kind of everyday activities and for these managers have to know the different advantages offered by entrepreneurial orientation activities, including the possibility of getting a significant increase in the level of growth and financial performance of the organization. Moreover, the entrepreneurial orientation also implies the development and implementation of formal and informal training programs that are fundamental, so employees and workers, from both micro and small enterprises have the necessary knowledge and skills to obtain the expected results.

Finally, a fifth implication obtained from these results is that managers of micro and 
small enterprises will have to create an organizational culture and environment, that facilitates the implementation and development of entrepreneurial orientation activities, as well as the transfer of knowledge and skills obtained in the company among the staff. According to Sadler-Smith et al. (2003), the management of cultural organization is closely linked to the level of financial performance of enterprises. Therefore, managers of micro and small enterprises will have to redirect their values and organizational culture to produce an innovative culture, which aims to the aspect teamwork with the staff of the organization as well as the workers of the main suppliers and commercial partners.

Additionally, this empirical research has some limitations that are necessary to mention. The first one is about the sample used as only micro enterprises (from 10 to 10 workers), and small enterprises (from 11 to 250 workers) were considered. That is why it would be advisable to consider micro enterprises with less than 5 workers, in order to confirm the results obtained. The second limitation is that the questionnaire applied to collect the data only considered micro and small enterprises in the state of Aguascalientes (Mexico). Future researches will need to apply the same questionnaire to micro and small enterprises in other states of the country, and even other countries of Latin America in order to verify whether the results obtained are similar or not.

A third limitation is that only entrepreneurial orientation, financial performance and firm growth were considered to measure the entrepreneurial orientation activities with qualitative variables, so in future investigations it will be necessary to consider quantitative variables such as the number of innovations implemented, or the return of investments in order to verify the results obtained. A fourth and final limitation is that the instrument applied to collect data only considered managers and/or owners of micro and small enterprises. This created the assumption in the research paper that they have a deep understanding about brand equity and business performance of their enterprises. Future research papers will need to apply the same questionnaire to employees and workers of small family and non-family enterprises in order to confirm the results obtained.

\section{Conclusion}

The results obtained in this empirical research allow us to conclude in three main aspects. Firstly, the entrepreneurial orientation activities carried out by micro and small enterprises have positive effects at the level of financial performance. Consequently, it is possible to conclude that the innovation activities, risk taking and the level of proactivity (entrepreneurial orientation) are essential to improve the financial performance of enterprises. Furthermore, if it is considered that one of the main goals for micro and small enterprises is the attainment of a better financial performance then organizations have to implement and/or improve their entrepreneurial orientation activities so they have more probabilities to achieve their goals. The results of this research are similar to the ones obtained in the investigations of Moroku (2013) and Coda et al. (2018) who also found a positive 
and significant relationship between both constructs.

Secondly, the entrepreneurial orientation activities also have positive effects at the level of growth in both micro and small enterprises. Therefore, it is possible to conclude that innovation, risk taking and the level of proactivity (entrepreneurial orientation), provide a higher level of firm growth, especially micro and small enterprises, because the different activities of entrepreneurial orientation facilitate the development of scale economies in organizations. In other words, they create the necessary conditions so micro and small enterprises, can achieve a higher firm growth so they can improve their levels of financial performance as well as their market position. These results are consistent with the ones obtained by Andersson and Tell (2009), who also found a positive and significant relation between both constructs.

Thirdly, the results obtained indicate that entrepreneurial orientation has a more positive and significant impact in the level of financial performance and the growth of micro and small enterprises. Thus, it is possible to conclude that microorganization of the manufacturing industry, are the ones adopting and implementing more those activities regarding innovation, risk taking and proactivity. As a result, it is also possible to conclude that the firms that develop more entrepreneurial orientation activities are micro companies. In other words, micro enterprises have a higher level of entrepreneurial orientation (they are more entrepreneurial) than small firms, which allows them not only to achieve a higher level of financial performance and growth but also survive in a highly competitive and globalized market. 


\section{References}

[1] AECA, Estrategia e Innovación de la Pyme Industrial en España. Madrid: Asociación Española de Contabilidad y Administración de Empresas. 2005.

[2] K. Ahmed and S.M. Zabri, The mediating effect of knowledge of inventory management in the relationship between inventory management practices and performance: The case of micro retailing enterprises, Journal of Business and Retailing Management Research, 12(3), (2018), 83-93.

[3] A. Al-Mamun and S. Ali-Fazal, Effect of entrepreneurial orientation on competency and micro-enterprise performance, Asia Pacific Journal of Innovation and Entrepreneurship, 12(3), (2018), 379-398.

[4] A. Al-Mamun, M.A. Ibrahim, N.C. Nawi and R. Muniady, Effect of economic vulnerability on entrepreneurial competencies among Malaysian microentrepreneurs, Asia Pacific Journal of Innovation and Entrepreneurship, 12(2), (2018), 222-237.

[5] A. Al-Mamun, R.A. Saufi and M.B. Ismail, Human capital, credit, and startup motives: A study among rural micro-enterprises in Malaysia, The Journal of Development Areas, 50(4), (2016), 383-400.

[6] S.A. Alvarez and L.W. Busenitz, The entrepreneurship of resource-based theory, Journal of Management, 27(6), (2001), 755-775.

[7] J. Andersén and J. Samuelsson, Resource organization and firm performance: How entrepreneurial orientation and management accounting influence the profitability of growing and non-growing SMEs, International Journal of Entrepreneurial Behavior \& Research, 22(4), (2016), 466-484.

[8] J. Anderson and D. Gerbing, Structural equation modeling in practice: a review and recommended two-step approach, Psychological Bulletin, 13(1), (1988), 411-423.

[9] S. Andersson and L. Tell, The relationship between the manager and growth in small firms, Journal of Small Business and Enterprise Development, 16(4), (2009), 586-598.

[10] D. Andrews, A.C. Sanchez and A. Johansson, Towards a better understanding of the informal economy. OECD Economic Department Working Papers, No. 873, OECD Publishing. Paris. 2011.

[11] E. Auttio and A. Lumme, Does the innovator role affect the perceived potential for growth? Analysis of four types of new, technology-based firms, Technology Analysis \& Strategic Management, 10(1), (1998), 41-54.

[12] R. Bagozzi and Y. Yi, On the evaluation of structural equation models, Journal of the Academy of Marketing Science, 16(1), (1988), 74-94.

[13] J.J. Ballow, B. McCarthy and M.J. Molnar, New concepts in value-based management: TRS mapping and total economic profit. Wellesley, MA: Accenture Institute for High Performance Business. 2004.

[14] P. Bentler, EQS 6 Structural Equations Program Manual. Encino, CA: Multivariate Software. 2005. 
[15] D.F. Berne, O grau de inovacao das indústrias MPE da regiao metropolitan oeste and sudoeste de Sao Paulo. Dissertacao de maestrao. Faculdade Campo Limpo Paulista. 2016.

[16] R. Blackburn, M. Hart and T. Wainwirght, Small business performance: Business, strategy and owner-manager characteristics, Journal of Small Business and Enterprise Development, 1(20), (2013), 8-27.

[17] M. Bowen, M., Morara and M. Mureithi, Management of business challenges among small and micro enterprises in Nairobi-Kenya, KCA Journal of Business Management, 2(1), (2009), 16-31.

[18] T. Brown, Confirmatory Factor Analysis for Applied Research. New York, NY: The Guilford Press. 2006.

[19] H.O. Bula, Evolution and theories of entrepreneurship: A critical review of the Kenyan perspective, International Journal of Business and Commerce, 1(11), (2012), 81-96.

[20] B. Byrne, Structural Equation Modeling With EQS, Basic Concepts, Applications, and Programming. 2th Edition. London; LEA Publishers. 2006.

[21] A. Carneiro, What is required for growth? Business Strategy Series, 8(1), (2007), 51-57.

[22] N. Caseiro and A. Coelho, Business intelligent and competitiveness: The mediating role of entrepreneurial orientation, Competitiveness Review: An International Business Journal, 28(2), (2018), 213-226.

[23] L. Cassia and T. Minola, Hypergrowth of SMEs: Towards a reconciliation of entrepreneurial orientation and strategic resources, International Journal of Entrepreneurial Behavior \& Research, 18(2), (2012), 179-197.

[24] D.S. Cho and H.C. Moon, From Adam Smith to Michael Porter: Evolution and Competitiveness Theory. Singapore: World Scientific Publishing Company. 2013.

[25] R. Coda, P. Viveiros and D. de Franca, Are small business owners' entrepreneurs? Exploring small business manager behavioral profiles in the Sao Paulo Metropolitan Region, RAUS Management Journal, 53(1), (2018), 152-163.

[26] J.G. Covin and D.P. Slevin, The development and testing of an organizationallevel entrepreneurship scale. In Ronstadt, R., Hornaday, J.A., and Vesper, K.H. (Eds.), Frontiers of Entrepreneurship Research. Wellesley, MA: Babson College. 1986.

[27] J.G. Covin and D.P. Slevin, Strategic management of small firms in hostile and benign environments, Strategic Management Journal, 10(1), (1989), 75-87.

[28] J.G. Covin and D.P. Slevin, A conceptual model of entrepreneurship as firm behavior, Entrepreneurship Theory and Practice, 16(1), (1991), 7-24.

[29] J.G. Covin, K.M. Green and D.P. Slevin, Strategic process effects on the entrepreneurial orientation-sales growth rate relationship, Entrepreneurship Theory and Practice, 30(1), (2006), 57-81.

[30] G. Darwis, Accelerated transformation of Indonesian SMEs: Embracing entrepreneurial orientation and innovation on achieving dynamic capability to 
increase competitiveness. 3rd International Indonesian Forum for Asian Studies: Borderless Communities and Nations with Borders, Challenges of Globalization. Yogyakarta. 2017.

[31] P. Davidsson, Continued entrepreneurship: Ability, need, and opportunity as determinants of small firm growth, Journal of Business Venturing, 6(6), (1991), 405-429.

[32] A. Davila, An exploratory study on the emergence of management control systems: Formalizing human resources in small growing firms, Accounting, Organizations and Society, 30(3), (2005), 223-248.

[33] A. Davila and G. Foster, Management accounting systems adoption decision: Evidence and performance implications from early-stage/startup companies, The Accounting Review, 80(4), (2005), 1039-1068.

[34] D. De Clercq, D. Dimov and N.T. Thongpapanl, The moderating impact of internal social exchange processes on the entrepreneurial orientationperformance relationship, Journal of Business Venturing, 25(1), (2010), 87103.

[35] G.G. Dess and G.T. Lumpkin, The role of entrepreneurial orientation in stimulating effective corporate entrepreneurship, Academy of Management Perspective, 19(1), (2005), 147-156.

[36] P. Dimitratos, S. Lioukas and S. Carter, The relationship between entrepreneurship and international performance: The importance of domestic environment, International Business Review, 13(1), (2004), 19-41.

[37] C. Fornell and D. Larcker, Evaluating structural equation models with unobservable variables and measurement error, Journal of Marketing Research, 18(1), (1981), 39-50.

[38] G. George, D. Robley-Wood and R. Khan, Networking strategy of boards: Implications for small and medium-sized enterprises, Entrepreneurship \& Regional Development, 13(3), (2001). 269-285.

[39] F. Gerli, P. Gubitta and A. Tognazzo, Entrepreneurial competencies and firm performance: An empirical study. VIII International Workshop on Human Resource Management Conference Proceedings, Seville. 2011.

[40] J.F. Hair, R.E. Anderson, R.L. Tatham and W.C. Black, Multivariate Data Analysis with Readings. New York, NY: Prentice-Hall. 1995.

[41] H. Hakala, Entrepreneurial and learning orientation: Effects of growth and profitability in the software sector, Baltic Journal of Management, 8(1), (2013), 102-118.

[42] L. Hatcher, A Step-by-Step Approach to Using the SAS System for Factor Analysis and Structural Equation Modeling, Cary, NC: SAS Institute Inc. 1994.

[43] R.L. Heneman, J.W., Tansky and M.S. Camp, Human resource management practices in small and medium-sized enterprises: Unanswered questions and future research perspective, Entrepreneurship Theory and Practice, 25(1), (2000), 11-26.

[44] R.D. Hisrich, P.P., Peters and D.A. Shepherd, Empreendedorismo. Porto Alegre: AMGH. 2014. 
[45] M. Hughes and R.E. Morgan, Deconstructing the relationship between entrepreneurial orientation and business performance at the embryonic stage of firm growth, Industrial Marketing Management, 36(5), (2007), 651-661.

[46] H.T. Keh, T.T.M., Nguyen and H.P. Ng, The effects of entrepreneurial orientation and marketing information on the performance of SMEs, Journal of Business Venturing, 22(4), (2007), 592-611.

[47] C.J. Kruger and R.D. Johnson, Assessment of knowledge management growth: A South Africa perspective, Aslib Proceedings: New Information Perspectives, 61(6), (2009), 542-564.

[48] L.C. Leonidou, C.N., Leonidou, T., Fotiades and A. Zeriti, Resources and capabilities as drivers of hotel Green marketing strategy: Implications on competitive advantage and performance, Tourism Management, 35(2), (2013), 94-110.

[49] D.A. Levinthal and J.G. March, The myopia of learning, Strategic Management Journal, 14(2), (1993), 95-112.

[50] J.C. Linder, Does innovation drive profitable growth? New metrics for a complete picture, Journal of Business Strategy, 27(5), (2006), 38-44.

[51] G.T. Lumpkin and G.G. Dess, Clarifying the entrepreneurial orientation construct and linking it to performance, Academy of Management, 21(1), (1996), 135-173.

[52] G.T. Lumpkin and G.G. Dess, Linking two dimensions of entrepreneurial orientation to firm performance: The moderating role of environment and industry life cycle, Journal of Business Venturing, 16(5), (2001), 429-451.

[53] D.W. Lyon, G.T., Lumpkin and G.G. Dess, Enhancing entrepreneurial orientation research: Operationalizing and measuring a key strategic decision making process, Journal of Management, 26(5), (2000), 1055-1085.

[54] T.W. Man, T., Lau and K.F. Chan, The competitiveness of small and medium enterprises: A conceptualization with focus on entrepreneurial competencies, Journal of Business Venturing, 17(2), (2002), 123-142.

[55] A. Mas-Tur, P., Pinazo, A.M. Tur-Porcar and M. Sánchez-Masferrer, What to avoid to success as an entrepreneur, Journal of Business Research, 68(11), )2015), 2279-2284.

[56] A. McKelvie, J.M. Haynie and V. Gustavsson, Unpacking the uncertainty construct: Implications for entrepreneurial action, Journal of Business Venturing, 26(3), 2(2011), 73-292.

[57] J.G. Messersmith and W.J. Wales, Entrepreneurial orientation and performance in young firms: The role of human resource management, International Small Business Journal, 31(2), (2011), 115-136.

[58] D. Miller, The correlates of entrepreneurship in three types of firms, Management Science, 29(7), (1983), 770-792.

[59] S. Mitchelmore and J. Rowley, Entrepreneurial competencies: A literature review and development agenda, International Journal of Entrepreneurial Behavior and Research, 16(2), (2010), 92-111. 
[60] A.M. Moreno and J.C. Casillas, Entrepreneurial orientation and growth of SMEs: A Causal model, Entrepreneurship Theory and Practice, 32(3), (2008), 507-528.

[61] R.K. Moroku, Does entrepreneurial orientation predict entrepreneurial behavior? International Journal of Entrepreneurship, 17(1), (2013), 41-60.

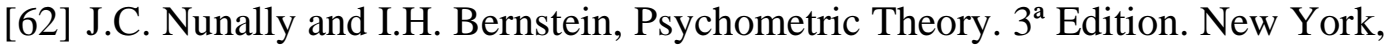
NY: McGraw-Hill. 1994.

[63] R.P. O'Shea, T.J., Allen, A., Chevalier and F. Roche, Entrepreneurial orientation, technology transfer and spinoff performance of US universities, Research Policy, 34(7), (2005), 994-1009.

[64] I. Peric, T., Grlandinovic, J., Kropivsek and K. Greger, Relationship between entrepreneurial competencies and firm performance: A study on furniture manufacturing SMEs in Croatia. 28th International Conference on Wood Science and Technology: Implementation of Wood Science in Woodworking Sector. Zagreb. 2007.

[65] L. Radulovich, R., Javalgi and R.F. Scherer, Intangible resources influencing the international performance of professional service SMEs in an emerging market: Evidence from India, International Marketing Review, 35(1), (2018), 113-135.

[66] A. Rauch, J., Wiklund, G.T., Lumpkin and M. Frese, Entrepreneurial orientation and business performance: An assessment of past research and suggestions for the future, Entrepreneurship Theory and Practice, 33(3), (2009), 761-787.

[67] E. Sadler-Smith, Y., Hampson, I., Chaston and B. Badger, Managerial behavior, entrepreneurial style, and small firm performance, Journal of Small Business Management, 41(1), (2003), 47-67.

[68] S. Saeed, S.Y., Yousafzai and A. Engelen, On cultural and microeconomic contingencies of the entrepreneurial orientation-performance relationship, Entrepreneurship Theory and Practice, 38(2), (2014), 255-290.

[69] S. Salojärvi, P., Furu and K.E. Sveiby, Knowledge management and growth in Finnish SMEs, Journal of Knowledge Management, 9(2), (2005), 103-122.

[70] N.A. Wahid, N.A., Aziz and R.A. Halim, Networking and innovation performance of micro-enterprises in Malaysia: The moderating effects of geographical location, Perrtanika Journal of Social Science and Humanities, 25(5), (2017), 281-292.

[71] W.J. Wales, P.C., Patel, V., Parida and P.M. Kreiser, Nonlinear effects of entrepreneurial orientation on small firm performance: The moderating role of resource orchestration capabilities, Strategic Entrepreneurship Journal, 7(2), 2013), 93-121.

[72] J. Wiklund and D. Shepherd, Knowledge-based resources, entrepreneurial orientation, and the performance of small and medium-sized business, Strategic Management Journal, 24(13), (2003), 1307-1314. 
[73] J. Wiklund and D. Shepherd, Entrepreneurial orientation and small business performance: A configurational approach, Journal of Business Venturing, 20(1), (2005), 71-91.

[74] J. Wiklund, P., Davidsson and F. Delmar, What do they think and feel about growth? An expectancy-value approach to small business managers' attitudes toward growth, Entrepreneurship Theory and Practice, 27(3), (2003), 247-270.

[75] P. Wolcott, M., Kamal and S. Qureshi, Meeting the challenges of ICT adoption by micro-enterprises, Journal of Enterprise Information Management, 21(6), (2008), 616-632.

[76] J.A. Wolff, T.L., Pett and J.K. Ring, Small firm growth as c function of both learning orientation and entrepreneurial orientation: An empirical analysis, International Journal of Entrepreneurial Behavior \& Research, 21(5), (2015), 709-730.

[77] S.A. Zahra, J.C., Hayton and C. Salvato, Entrepreneurship in family vs. nonfamily firms: A resource-based analysis of the effect of organizational culture, Entrepreneurship Theory and Practice, 28(4), (2004), 363-381. 